\section{OPEN ACCESS}

Edited by:

Minela Kerla,

Consultant, Sarajevo,

Bosnia and Herzegovina

Reviewed by:

Johan Buitendag,

University of Pretoria, South Africa

Wendy Purcell,

Harvard University, United States

*Correspondence:

Joseph Roche

Joseph.Roche@tcd.ie

Specialty section:

This article was submitted to

Sociological Theory,

a section of the journal

Frontiers in Sociology

Received: 03 October 2020 Accepted: 09 November 2020 Published: 02 December 2020

Citation:

Roche J, Bell L, Galvão C Golumbic YN, Kloetzer L, Knoben N, Laakso M, Lorke J, Mannion G

Massetti L, Mauchline A, Pata K,

Ruck A, Taraba P and Winter S (2020)

Citizen Science, Education, and

Learning: Challenges and Opportunities.

Front. Sociol. 5:613814 doi: $10.3389 /$ fsoc.2020.613814

\title{
Citizen Science, Education, and Learning: Challenges and Opportunities
}

\begin{abstract}
Joseph Roche ${ }^{1 *}$, Laura Bell ${ }^{1}$, Cecilia Galvão ${ }^{2}$, Yaela N. Golumbic ${ }^{3}$, Laure Kloetzer ${ }^{4}$, Nieke Knoben ${ }^{5}$, Mari Laakso ${ }^{6}$, Julia Lorke ${ }^{7}$, Greg Mannion ${ }^{8}$, Luciano Massetti ${ }^{9}$, Alice Mauchline ${ }^{10}$, Kai Pata ${ }^{11}$, Andy Ruck ${ }^{12}$, Pavel Taraba ${ }^{13}$ and Silvia Winter ${ }^{14}$

${ }^{1}$ Trinity College Dublin, Dublin, Ireland, ${ }^{2}$ University of Lisbon, Lisbon, Portugal, ${ }^{3}$ University of Sydney, Sydney, NSW, Australia, ${ }^{4}$ University of Neuchâtel, Neuchâtel, Switzerland, ${ }^{5}$ Naturalis Biodiversity Centre, Leiden, Netherlands, ${ }^{6}$ Ministry of Agriculture and Forestry, Helsinki, Finland, ${ }^{7}$ Wissenschaft im Dialog, Bürger Schaffen Wissen, Berlin, Germany, ${ }^{8}$ University of Stirling, Stirling, United Kingdom, ${ }^{9}$ Institute of Bioeconomy, Italian National Research Council, Rome, Italy, ${ }^{10}$ University of Reading, Reading, United Kingdom, ${ }^{11}$ Tallinn University, Tallinn, Estonia, ${ }^{12}$ University of the Highlands and Islands, Perth, United Kingdom, ${ }^{13}$ Tomas Bata University in Zlin, Zlin, Czechia, ${ }^{14}$ Vienna University of Natural Resources and Life Sciences, Vienna, Austria
\end{abstract}

Citizen science is a growing field of research and practice, generating new knowledge and understanding through the collaboration of citizens in scientific research. As the field expands, it is becoming increasingly important to consider its potential to foster education and learning opportunities. Although progress has been made to support learning in citizen science projects, as well as to facilitate citizen science in formal and informal learning environments, challenges still arise. This paper identifies a number of dilemmas facing the field-from competing scientific goals and learning outcomes, differing underlying ontologies and epistemologies, diverging communication strategies, to clashing values around advocacy and activism. Although such challenges can become barriers to the successful integration of citizen science into mainstream education systems, they also serve as signposts for possible synergies and opportunities. One of the key emerging recommendations is to align educational learning outcomes with citizen science project goals at the planning stage of the project using co-creation approaches to ensure issues of accessibility and inclusivity are paramount throughout the design and implementation of every project. Only then can citizen science realise its true potential to empower citizens to take ownership of their own science education and learning.

Keywords: learning environments, teachers, ontology and epistemology, activism, science communication, public engagement

\section{INTRODUCTION}

Citizen science has long been considered to hold vast potential in the field of science education and learning (Bonney et al., 2009a). It is also a rapidly growing field of research in its own right, with increasing prominence in areas such as astronomy, ecology, meteorology, and medicine (Lewandowski et al., 2017). As the term "citizen science" applies to science that involves people who are not professional scientists, it occupies a unique position in the scientific community. As well as being its own distinct field of enquiry (Jordan et al., 2015), it can also reach beyond individual scientific disciplines 
to attract wider public participation in scientific research, leading to the overall advancement of scientific knowledge (Bonney et al., 2009b). Citizen science has ample capacity for transdisciplinarity and for integrating natural, physical, and health sciences with the humanities and social sciences (Pykett et al., 2020; Tauginiene et al., 2020). It is an excellent method of harnessing non-traditional data sources to tackle societal challenges and contribute to certain Sustainable Development Goals of the United Nations (Fritz et al., 2019; Fraisl et al., 2020).

A number of associations have been established world-wide, with the aim of bringing together people who are involved in citizen science. The most distinguished of these are the Citizen Science Association (ostensibly a US-based association, but offering global membership), the European Citizen Science Association, and the Australian Citizen Science Association. Each of these relatively new associations have highlighted education and learning as critical issues for citizen science as an emerging professional field (Storksdieck et al., 2016; Roche and Davis, 2017a). Citizen science has the capacity to "develop connections between students' everyday lives and science so that they will have tangible reasons for continuing with the lifelong learning of science" (Jenkins, 2011, p. 501). It can function as a means of engaging the public with science on the scale of individual experiments, creating a unique position of combining participation, monitoring, and social change (Doyle et al., 2019; Dawson et al., 2020). Citizen science also offers a route by which the tenets of responsible research and innovation (Owen et al., 2012) may be fulfilled, particularly by facilitating lesserheard communities in having their voices heard in relation to scientific policy-making and governance. This is now of more importance than ever, as researchers and academic experts find society's trust in their authority diminished (Roche and Davis, 2017b), while the COVID-19 pandemic has demonstrated the acute need for public trust to be strengthened (Henderson et al., 2020). Indeed, citizen science might offer a more pressing model for science in a post-pandemic world (Provenzi and Barello, 2020). Despite its growing importance, citizen science is rarely considered in terms of science education research (KelemenFinan et al., 2018). For the purposes of this paper, the term "science" is taken to encompass systematic and evidence-based investigations in the pursuit of new knowledge, while the term "education" is considered to be the acquisition of knowledge through learning. Learning can be self-directed, but often relies on the guidance of a teacher. The learning can take place in either formal or informal environments and the methods of teaching, or pedagogy, can be as varied as the settings themselves. While these definitions are not all-inclusive, they provide a starting point where science, education, and learning can be considered in relation to the emerging challenges and opportunities stemming from citizen science.

\section{Supporting Citizen Science in Education and Learning}

In order to ensure that citizen science lives up to its vast potential to extend beyond individual projects and disciplines, opportunities for strengthening the relationship between citizen science and education must be identified so that appropriate support can be offered and integration achieved. Many questions have been raised regarding the role of citizen science within science education (Bonney et al., 2016); even the term "citizen science," and the individual component words of that term can have different meanings subject to context (Eitzel et al., 2017). A report prepared by the US National Academies of Sciences, Engineering, and Medicine set out to tackle these issues-not simply by discussing the "potential of citizen science to support science learning" but by endeavouring to "identify promising practices and programs that exemplify the promising practices, and lay out a research agenda that can fill gaps in the current understanding of how citizen science can support science learning and enhance science education" (National Academies of Sciences, 2018, p. 2).

In Europe, efforts are also underway to identify the challenges and opportunities that may arise when citizen science and education are brought together through project collaboration, networks, research, and practice. Alongside the European Commission's "Science with and for Society" work programme (European Commission, 2017), and the European Citizen Science Association, a COST Action (CA15212) was also established in order "to promote creativity, scientific literacy, and innovation throughout Europe" through citizen science (COST, 2016). This COST Action included a working group entitled "Develop synergies with education" and, through a dedicated workshop, brought together researchers and practitioners with a range of different backgrounds and contexts for interpreting citizen science in relation to education and learning. The subsequent discussions that emerged from the working group led to this paper, which provides an international perspective on some of the main challenges and opportunities facing citizen science in education. While the diversity of the working group ensured that a broad selection of perspectives were considered, it was by no means exhaustive. There are undoubtedly other arising challenges and opportunities that have not yet been considered, and it is hoped that this paper will serve as a starting point for developing a comprehensive research agenda for supporting citizen science in education and learning.

\section{CHALLENGES FOR CITIZEN SCIENCE, EDUCATION, AND LEARNING}

Every person who participates in citizen science is also involved in a learning process (Bela et al., 2016), not just the acquisition of the skills necessary for participation in citizen science, but also a deeper understanding of scientific concepts and processes-historically referred to as "scientific literacy" (Miller, 1983). The development of scientific literacy in tandem with the contribution to genuine scientific outcomes has been a longstanding goal of the field (Brossard et al., 2005; Jordan et al., 2011; Saunders et al., 2018). Logistical tensions tend to arise between citizen science and education due to unavoidable constraints concerning time, space, staff, and other key resources. While training could help address a number of these issues, the 
associated costs often present a barrier, especially in fields where participant goodwill and volunteer work are crucial (Lorke et al., 2019). Many citizen science projects have little flexibility in terms of timing and the allocation of resources, and navigating these issues will invariably remain challenging for many citizen science coordinators and programme managers.

Beyond logistics, the goal of citizen science-to bring about scientific progress-and the goal of education-to support learning - may not necessarily always align. Citizen science can be integrated into education in both formal and informal learning environments. Formal learning generally occurs in school, college, or university environments with clear learning objectives, whereas informal education can take place outside of the classroom or after school, often in public engagement spaces like museums, zoos, or aquariums (Eshach, 2007; National Research Council, 2009). Each environment raises unique challenges for practitioners. Challenges may also arise as a result of the different needs of the scientists, students, teachers, educators, researchers, and other actors involved; the issue of how information is communicated and shared; as well as from potential conflict between the capacity of citizen science for activism and the desire or obligation to reach specific learning objectives.

\section{Citizen Science and Education in Formal Learning Environments}

Specific learning objectives, background information, and lesson plans are generally utilised by educators to integrate citizen science projects into curricula in formal learning environments, particularly when teaching children and adolescents at primary and post-primary level (Bonney et al., 2009b, 2014). Consequently, project engagement becomes contingent on the educators themselves; as the students or learners may have been effectively volunteered to participate, rather than electing to do so, motivation and engagement may be lacking compared to other groups of citizen science participants. Therefore teachers, as the citizen science intermediaries in formal learning environments (Weinstein, 2012), play a crucial role in successfully integrating such projects into their classrooms and schools. That some teachers may lack confidence in their own general level of scientific content knowledge and scientific literacy can considerably impede this process-for example, issues of content knowledge could arise on projects that require teachers to explore outdoor environments where they cannot fulfil the perceived demand to be an expert (Kelemen-Finan and Dedova, 2014; Jenkins et al., 2015). The participation of schools can also be constrained by school curricula, timetables, or logistical issues. For those teachers and schools that are interested in engaging in citizen science projects, it may be difficult to navigate the rapidly growing number of initiatives available to them.

Additional challenges stem from the type of classroom involvement that can be facilitated. Projects such as the Monarch Larva Monitoring Project (Kountoupes and Oberhauser, 2008) or Classroom FeederWatch (Bonney and Dhondt, 1997) are considered examples of best practice from the last two decades, where materials are provided for local school involvement, while generating valuable data for the project at large. Both of these projects offer web tools for downloading data, as well as instructions for data analysis to empower participants to perform their own analysis. The construction of materials, the maintenance of an interactive website, smartphone apps, and continuous email contact requires considerable resources, especially in terms of staff with relevant experience in science and education. More recent projects like the School of Ants (Lucky et al., 2014), LandSense (Olteanu-Raimond et al., 2018), and eMammal (Schuttler et al., 2019) have mirrored the success of these large-scale schools projects, while national schools-based citizen science projects in the future are likely to tackle aspects of post-pandemic life (Eichler et al., 2020; Ugolini et al., 2020). Smaller contributory projects sometimes lack such infrastructure and resources and, consequently, participants are often only involved in data collection without gaining experience of the complete inquiry process (Jenkins et al., 2015). Zoellick et al. (2012) argue that a third party, for example, a university, is a necessary intermediary between scientists and educators in order to ensure that specific research and educational outcomes are ultimately achieved. Their proposed model for school-based research projects describes scientists' and educators' inputs, their interactions during the design and implementation phase, and separate outputs and outcomes for students and scientists. While this model addresses the tension between collaborating scientists, schools, teachers, and students, it could be further improved with the added consideration of student input alongside outcomes for the educators (Jenkins, 2006). Co-constructed citizen science projects, where students are actively involved in the scientific process are labour and resource intensive for scientists, students, and teachers, but are more likely to achieve the scientific and educational goals of the project (Gray et al., 2012).

\section{Citizen Science and Education in Informal Learning Environments}

Informal education generally refers to the learning that takes places outside of classrooms and lecture theatres. Informal environments may sometimes be further subdivided into nonformal and semiformal categories (Werquin, 2007), but for the purpose of this paper, all learning environments outside of those involving schools, higher education, or universities, can be considered informal. Informal learning environments, such as science centres and museums, are critical to science education. Citizen science projects find a natural home in these domains due to a shared strong commitment to public engagement (Dickinson et al., 2012; Ballard et al., 2017).

The impact that citizen science projects can have on education in these environments is affected by the same challenge that faces informal learning environments in general-finding the best way to support learners and facilitators (Stewart and Jordan, 2017). Tension may arise between designing projects that are "fun" for casual participants and ensuring that data generated is of sufficient quality. The use of "fun" activities can increase participation, create interest in a given research topic, and nurture a love of science-particularly in projects involving young people (Kountoupes and Oberhauser, 2008). However, 
there may be a trade-off regarding the time and resources necessary to make these activities engaging, and the efforts to serve the scientific and educational goals of the project. A report by the US Committee on Learning Science in Informal Environments in 2009 found that although tensions often arise between the "reasonable goals for learning science in informal environments" and the education "agenda," it was deemed 'unproductive to blindly adopt either purely academic goals or purely subjective learning goals' in informal learning settings (Bell et al., 2009, p. 3).

The learning that takes place in informal environments through citizen science projects can be difficult to capture. Initial efforts have been undertaken to find ways to evaluate the intended learning outcomes for the participants in these projects (Phillips et al., 2014, 2018), but Edwards (2014) has highlighted that the specific impact that citizen science can have on the lifelong learning of people outside the classroom has not yet been comprehensively explored. Likewise, while understanding social and cultural capital is critical to interpreting how people engage with informal science education institutions (Dawson, 2014), there has not yet been enough consideration given to how this capital affects participation in citizen science projects and the resulting issues of equity that may emerge (Birmingham, 2016). Citizen science has the same issues of inequity that are endemic throughout society, with innate barriers to participation for minorities and underserved communities (Soleri et al., 2016; Fiske et al., 2019). Science capital-a concept that explores how a person's environment and social class can affect their involvement in science-could allow "inequalities in science participation" to be discovered more readily, which in turn could be used to promote "social justice within science education" (Archer et al., 2015, p. 943). If citizen science is to fulfil its potential in improving equity of access to, and participation in, both science and science education in informal learning environments, then "the extent to which citizen science can build science capital and enable wider engagement with science-related issues [...] deserves further experimentation and investigation" (Edwards et al., 2018, p. 390).

\section{Citizen Science, Education, and Activism}

Arnstein (1969) pioneered the concept of citizen participation with her "Ladder of Citizen Participation," which described the eight levels of citizen power, from non-participatory "manipulation" to "citizen control." The role citizen science may play in activism and in advocacy-citizens intervening on behalf of, or representing, a socio-political goal (Letiecq and Anderson, 2017; Reis, 2020) - is a key consideration in its interactions with education and learning. From the perspective of civic society, citizen science should encourage individuals to take an active role in their communities-operationalizing active citizenship (Burls and Recknagel, 2013). This role of active citizenship aligns with Arnstein's rising level of citizen participation and is especially pertinent in citizen science projects that focus on environmental activism and climate changeempowering people to take responsibility for the future of their environments (Baptista et al., 2018; Kythreotis et al., 2019; Dawson et al., 2020). The concept of active citizenship is closely aligned to the UNESCO Incheon Declaration and Framework for Action (UNESCO, 2015) which seeks to ensure inclusive, equitable, and quality education on a global scale. It encompasses three distinct dimensions: a citizen's legal citizenship, socioeconomic background, and socio-cultural background (KalekinFishman et al., 2007). Legal citizenship enables an individual to channel their political agency, although, as highlighted by Eitzel et al. (2017), the definition of citizenship is complex and can be problematic in some contexts. Socio-economic power can create demand for education, transforming learning into a desirable consumer commodity and potentially creating resources that can supplement underfunded or overlooked government services. The socio-cultural dimension of active citizenship focuses on ethics, and seeks to foster cohesion, inclusion, and tolerance in the personal and public spheres. Citizen science practice could be exercised as one means of educating active citizens; by empowering communities to advocate for their local environment through research, or by enabling citizens to gather evidence on, and articulate, pressing issues. The results of active citizenship, often shared with the wider public through social media, can even hasten the actions of decision-makers (Eitzel et al., 2017).

However, despite the benefits of potentially bolstering science education through active citizenship, tension may arise between the traditional role of the learner in some learning environments, acquiring pre-determined knowledge and values, and the process of learning continuously through active citizenship, which may result in social transformation. Educators may feel uncomfortable in sharing decision-making power with other participants in citizen-led activities and may feel uncertainty as to the value of that learning process (Mueller and Tippins, 2015). In citizen science activities, practitioners, and participants may not be able to retain their usual roles in some learning environments (Fazio and Karrow, 2015) and significant changes may need to be made in order to enable and facilitate social activism.

\section{Theoretical Perspectives on Citizen Science and Educational Practice}

Ontologies and epistemologies are theories surrounding the nature of being and knowing, or generating knowledge, and provide the assumptions which naturally underlie both educational practice and citizen science practice. Ontology and epistemology are often linked, because how the world is understood, and the phenomena that are available for study within it, are very much dependent on how people think they can come to know, and what they consider "valid" knowledge. Therefore, onto-epistemological differences, namely, tensions that arise from the disparate ways each person interprets the world, including the understanding of what phenomena can be studied, how it can be studied, and the conclusions that can subsequently be drawn, mean that the differences inherent between various citizen science fields and educational environments will result in disparate learning outcomes. As noted by Shirk et al. (2012), tension may be generated due to the often dissimilar interests of scientific and public stakeholder groups in the wider field of public participation 
in scientific research (PPSR), in which citizen science is intrinsic. Competing onto-epistemologies are likely contributory factors to the difficulties inherent in engaging various publics in scientific research, and the alignment of these competing constituents could facilitate greater synergy between citizen science and education.

Building on Arnstein's concept, Haklay (2013) designed an adapted model for citizen science in which the fourth and final level of citizen participation enables all stakeholdersscientists, educators, facilitators, the public, education partner organisations, and policy makers-to collaborate. At this level, citizen science would emerge as a truly transformative practice that has the power to change and influence the world. In his typology, Haklay's (2013) suggests that increasing the involvement and engagement of the public in citizen science will result in the empowerment of learners while significantly democratising citizen science input. As members of the public are empowered to engage more deeply with, and learn more about the scientific projects they are involved in, they are likely to move up the structure-from merely acting as sensors for science projects that are conducted elsewhere, to collaboratively shaping scientific endeavours from their inception, and participating in their analysis throughout.

Competing tensions in citizen science can also be considered through three stances in education suggested by Stetsenko's (2008) acquisition, participation, and transformation - which are evident at each level of Haklay's typology. In the first stance, "acquisition," stakeholders see citizen science processes as being concerned with generating pre-existing, fixed, factual knowledge that is gained by individuals primarily through passive input. The second stance, "participation," positions science and education practices as potentially being affected by other factors-such as location or culture-and necessitates an initiation process in order for participants to gain full access to the community. This stance places citizen scientists into a more participatory role, and educators and scientists are aware that citizen science often generates findings that are culturally located, generated, shared, mutable, and communicated over time. This stance may bring about tension from stakeholders who don't wholly subscribe to the idea that findings are culturally embedded; however, "participation" provides access for novices, e.g., pupils, into the community of science practitioners.

Applying Stetsenko's third stance, citizen science can become "transformative" when embedded in educational programming. This transformation could lead to change at individual, community-wide, and global levels if citizen science expands in scale and scope. The intrinsic risk of the transformative approach is that it can replace a system of knowledge with one that still does not appropriately recognise marginalised forms of knowledge (Leibowitz, 2017). An example of a transformative project could be "WeatherBlur" a co-created citizen science project bringing together, fishermen, students, teachers, and research scientists from island and coastal communities on the east coast of the US "to share, analyse, and interpret data about the local impact of climate change" (Kermish-Allen et al., 2019, p. 627). "Knowing" and acquiring knowledge are presented by Stetsenko as active and collective activities; thus citizen science would evolve into a collaborative, co-creative approach. This transformative stance embodies the fourth level of Haklay's typology; presenting an ideal common ground for both education and citizen science, resolving potential onto-epistemological tensions, and generating synergy.

\section{Dissemination, Dialogue, and Participatory Communication}

Citizen science projects often aim not only to advance scientific knowledge, but to share it too. The manner in which communication takes place in these projects, and the effect it has on learning, must tread the line between outreach and engagement, and warrants a communication plan that not only connects with the right audiences but retains their interest over time (Veeckman et al., 2019). Projects tend to adopt either a twoway approach that emphasises participatory dialogue (McCallie et al., 2009; Haywood and Besley, 2013), or a one-way approach that focuses on outreach and dissemination.

Two-way communication between citizens and scientists within projects leads to the sharing of ideas, information, and knowledge, while one-way dissemination to a wider audience can involve the communication of results, fundingspecific public relations obligations, or participant recruitment (Tulloch et al., 2013; Groulx et al., 2017). While the two-way participatory approach is more time consuming, and can put additional pressure on project resources, it is more likely to foster collaborative work, relationship building, and learning (Mercer and Littleton, 2007). The tension between outreach and engagement is mirrored in the field of science communication with its models of deficit and dialogue (Trench, 2008; Lewenstein, 2015).

Whereas participatory engagement is a powerful way to support learning (Gleason and Von Gillern, 2018), one-way dissemination also has a valuable role in citizen science. Communicating the mission and vision of a project outside of its immediate community can be one of the most important goals for project leaders (Kerzner, 2013). The way in which these values are communicated can vary, depending on the scientists, citizens, and policymakers involved. In particular, there is often a perceived disconnect between policymakers and other key stakeholders, such as citizens and scientists (Socientize Consortium, 2013). Using a Public Relations (PR) approach is a commonly employed method of bridging this gap (Scott, 2013), and involves implementing a strategic communications plan that can include public lectures, workshops, festivals, exhibits, tours, and open laboratories. To supplement these activities, a strategic PR plan for citizen science projects is often used to directly engage policymakers with demonstrations of the usefulness of the project and the need for new knowledge generation (Socientize Consortium, 2014). Although a common concern when employing a communication approach that focuses on PR is the potential tendency to overlook negative results and issues of uncertainty, which are part of the scientific process, if effective communication is adhered to between stakeholders, it can lead to citizen science projects enhancing public debate and citizen participation in decision-making 
processes, especially regarding societal challenges (Newman et al., 2012).

In as much as onto-epistemological tensions may arise between citizen science and education, one-way dissemination may generate significant tension in a learning environment when science is positioned as the sole truth, and the scientific method the only way to produce reliable knowledge. A twoway participatory approach, by contrast, not only bridges the gap between science education and science communication but poses science as one of many types of knowledge, and the scientific method as one of a multitude of ways to describe the world (Baram-Tsabari and Osborne, 2015). This interplay between science and society is ever more critical in the era of fake news and misinformation (Scheufele and Krause, 2019). One of the most effective solutions to such tensions is to involve scientists in all aspects of the communication process in citizen science projects (Riesch and Potter, 2014). This has a positive effect on participant recruitment, retention, instruction, knowledge sharing, awareness raising, and increases the credibility and authority of the work taking place. However, some scientists may be hesitant to engage in efforts to communicate if they feel that they are not specifically trained to do so (Golumbic et al., 2017). Communication activities, such as public talks, interviews, or popular science articles can be time consuming, and some scientists may find participation uncomfortable (Van Vliet et al., 2014). An increasing number of research funding initiatives at both national and European levels require the inclusion of public engagement and communication strategies, thus increasing the pressure on scientists involved in citizen science projects to directly engage with public audiences. This may be particularly challenging for scientists if these activities are not supported by their institutions, or if their career progression is primarily evaluated on the quality of their publications in scientific journals (Kreiman and Maunsell, 2011). While not without its critics (Khazragui and Hudson, 2015; Watermeyer, 2016), the Research Excellence Framework in the UK is a notable example of a research evaluation process that gives consideration to the societal impact of research.

\section{OPPORTUNITIES FOR CITIZEN SCIENCE, EDUCATION, AND LEARNING}

Thoroughly exploring the obstacles that prevent the successful integration of citizen science practice into mainstream education systems is key to overcoming them. Recommendations based on the challenges that have been highlighted in this paper could help citizen science to fulfil its potential as a truly transformative social innovation for education and learning. This could, in turn, encourage citizen science practitioners and educators to take an adaptive and flexible position in the face of new and emerging societal challenges and a fluctuating political and economic landscape that continuously strains the relationship between science and society.

\section{Recommendations for Finding Synergy}

There has already been a great deal of work conducted with a view to establishing best practice principles for citizen science notably, the European Citizen Science Association's "Ten Principles of Citizen Science" [European Citizen Science Association, 2015; and the subsequent characteristics of citizen science (European Citizen Science Association, 2020) which expand on the principles]. Assuming adherence to these principles, the following recommendations may create meaningful opportunities for citizen science in education and learning.

Professional development training workshops (Jeanpierre et al., 2005) facilitating citizen science in classrooms can be effective in overcoming some of the barriers that schools, teachers, and students may encounter while participating in citizen science projects (Eberbach and Crowley, 2009; Scheuch et al., 2018). Crall et al. (2013) demonstrated that such workshops could improve scientific literacy for workshop participants, assessed with context-specific measures. However, unique challenges are still likely to arise. Jordan et al. (2011) could not detect any increase in scientific literacy, and the potential failure of these training sessions was attributed to a lack of time for active learning, which must provide a provision for reflection, and allow participants to make mistakes (Gray et al., 2012; Jordan et al., 2015). To further embed citizen science in informal learning spaces, gamification is an effective tool in engaging participants, and in-game rewards can be carefully planned in order to reward focus on good quality data (Tippins and Jensen, 2012; Bowser et al., 2013; Morschheuser et al., 2019; Piper, 2020).

Ensuring alignment between the onto-epistemological positions of the citizen science, education, and learning aspects of any project is a worthwhile endeavour. It is clear that the achievement of the educational goals of citizen science projects are contingent on those goals being taken into consideration at the design stage (Bonney et al., 2014). Following frameworks for measuring individual learning outcomes from participation in citizen science-such as Phillips et al. (2018) — would facilitate the alignment of learning outcomes and the underlying ontoepistemological stances. Additionally, building a co-creation component into citizen science projects from the outset would significantly increase the likelihood that both the educational and scientific goals of the project will be met (Gray et al., 2012). Such co-creation approaches should be considered obligatory, where possible, for every new project.

Challenges surrounding communication, dissemination, and dialogue may be addressed by increasing science communication training opportunities for scientists involved in citizen science, as well as for scientists in general. Collaboration between scientists and citizens with public relations and communication professionals could lead to more open strategies for communicating with different audiences and could generate clear alignment between both the dissemination and participatory modes of communication. Crucially, to ensure that scientists contribute not only to the scientific goals of citizen science projects, but also to the communication and educational aspects, public engagement 
should be recognised as scholarly work. This would be made possible through research institutions redefining public engagement as a metric to be evaluated in academic career progression, in a manner akin to research output (Smith et al., 2014).

The greater recognition of citizen science and activism in recent years may, in part, be due to a growing focus on equality, open access, and public participation caused by the current global political climate (Roche and Davis, 2017b; Hutter and Kriesi, 2019). Once public engagement is fully integrated into the missions of both research performing organisations and research funding organisations, social activism must be given due consideration as an inevitable counterpart to citizen science. As recommended by the National Academies of Sciences (2018), issues of equity and power should be given particular consideration at all stages of citizen science project design and implementation, in all settings. Citizen science is not merely a method of involving the public in scientific research but is also a way of empowering citizens to take ownership of their own science education and learning.

\section{The Future of Citizen Science in Education and Learning}

Transformative approaches to education are becoming more widely accepted; within education, and in higher education specifically, there is significant interest in developing coresearcher partnerships (Healey et al., 2016). Such partnerships can lead to the co-design of curricula (Bovill, 2014) and the co-production of knowledge (McCulloch, 2009). A contributory approach necessitates a whole new learning paradigm requiring novel educational methods. The outdated metaphor of 'students as consumers' (Dearing, 1997; Palfreyman and Warner, 1998), which has a negative impact on student engagement and performance (Bunce et al., 2017), could be replaced by a citizen science partnership that supports educators and students, where knowledge is exchanged in both directions, and the students are active partners in their learning (Freeman et al., 2014) and in participating in authentic scientific research.

Citizen science practitioners and programmes seeking links with schools may find that tapping into more transformative models of learner engagement is a starting point for enhanced participation. The adoption of a transformative ontoepistemological stance opens up much greater potential for synergy between citizen science and education. The outcomes of transformative citizen science will result in changes to what is known, how it is known, and to the individual, socio-cultural, and wider world. Mueller and Tippins (2012) rhetorically ask why citizen science programming in education generally aims to advance science literacy, when learners' motivations are predominantly to care for what is often a local environment. Within this transformational framing, potential exists for attending to learning and practicing science in ways that are more in tune with learners' motivations, with local places, and in ways that are socio-culturally distributed among all participants, including scientists, teachers, students, community members, policymakers, and any other stakeholders (Mannion et al., 2013; Haywood et al., 2016). Taking a transformative stance on citizen science in education could be key to engendering a more vital role for science in the public sphere, generating responses to current and future eco-social problems (Dillon et al., 2016), and helping to achieve the UN Sustainable Development Goals (Fritz et al., 2019; Fraisl et al., 2020).

The future of how citizen science will be integrated into education and learning will continue to be influenced by globally-accessible digital platforms. The newest of these, EUCitizen.Science, is an online platform for citizen science in Europe that is being established with the support of a Horizon 2020 grant from the European Commission. This platform will not only make citizen science projects and data more readily accessible, but it will also act as a mutual learning space for sharing useful tools, guidelines, training, and best practice examples in several languages to help citizens, scientists, teachers, students, schools, and other stakeholders to determine how they can engage with local and international citizen science projects. Global initiatives such as these will be key to realising the education and learning potential of citizen science as a farreaching social innovation.

\section{AUTHOR CONTRIBUTIONS}

JR and SW were the lead authors and oversaw the completion of the writing. JR, LB, CG, YG, LK, NK, ML, JL, GM, LM, AM, KP, $\mathrm{AR}, \mathrm{PT}$, and SW contributed writing to individual subsections of the manuscript. All authors have read and agreed to the published version of the manuscript and were involved in the conceptual design of the manuscript.

\section{FUNDING}

This work would not have been possible without the support of the COST (European Cooperation in Science and Technology) Action CA15212 (Citizen Science to promote creativity, scientific literacy, and innovation throughout Europe) and the EU-Citizen Science project which received funding from the European Union's Horizon 2020 Research and Innovation Programme under Grant Agreement No. 824580.

\section{ACKNOWLEDGMENTS}

The authors are grateful to Working Group 2 (Develop synergies with education) of the COST Action CA15212 (Citizen Science to promote creativity, scientific literacy, and innovation throughout Europe) which brought the authors together and provided a platform to collaborate on this paper. 


\section{REFERENCES}

Archer, L., Dawson, E., DeWitt, J., Seakins, A., and Wong, B. (2015). "Science capital": a conceptual, methodological, and empirical argument for extending bourdieusian notions of capital beyond the arts. J. Res. Sci.Teach. 52, 922-948. doi: $10.1002 /$ tea.21227

Arnstein, S. (1969). A ladder of citizen participation. J. Am. Inst. Plann. 35, 216-224. doi: 10.1080/01944366908977225

Ballard, H. L., Robinson, L. D., Young, A. N., Pauly, G. B., Higgins, L. M., Johnson, R. F., et al. (2017). Contributions to conservation outcomes by natural history museum-led citizen science: examining evidence and next steps. Biol. Conserv. 208, 87-97. doi: 10.1016/j.biocon.2016.08.040

Baptista, M., Reis, P., and Andrade, V. (2018). Let's save the bees! An environmental activism initiative in elementary school. Vis. Sustain. 9, 41-48. doi: 10.13135/2384-8677/2772

Baram-Tsabari, A., and Osborne, J. (2015). Bridging science education and science communication research. J. Res. Sci. Teach. 52, 135-144. doi: 10.1002/tea. 21202

Bela, G., Peltola, T., Young, J. C., Balázs, B., Arpin, I., Pataki, G., et al. (2016). Learning and the transformative potential of citizen science. Conserv. Biol. 30, 990-999. doi: 10.1111/cobi.12762

Bell, P., Lewenstein, B., Shouse, A. W., and Feder, M. A. (2009). Learning Science in Informal Environments: People, Places, and Pursuits. Committee on Learning Science in Informal Environments. Washington, DC: National Academies Press.

Birmingham, D. (2016). "Disorienting, fun or meaningful?": looking beyond the boundaries of the museum. Cult. Stud. Sci. Educ. 11, 953-958. doi: 10.1007/s11422-015-9705-5

Bonney, R., Ballard, H., Jordan, R., McCallie, E., Phillips, T., Shirk, J., et al. (2009a). Public Participation in Scientific Research: Defining the Field and Assessing Its Potential for Informal Science Education. A CAISE Inquiry Group ReportAQ publisher.

Bonney, R., Cooper, C. B., Dickinson, J., Kelling, S., Phillips, T., Rosenberg, K. V., et al. (2009b). Citizen science: a developing tool for expanding science knowledge and scientific literacy. BioScience 59, 977-984. doi: 10.1525/bio.2009.59.11.9

Bonney, R., and Dhondt, A. A. (1997). "FeederWatch. An example of a studentscientist partnership," in Internet Links for Science Education. Innovations in Science Education and Technology, Vol. 4, ed C. K. Cohen (New York, NY; London: Plenum Press), 31-53. doi: 10.1007/978-1-4615-5909-2_4

Bonney, R., Phillips, T. B., Ballard, H. L., and Enck, J. W. (2016). Can citizen science enhance public understanding of science? Public Underst. Sci. 25, 2-16. doi: $10.1177 / 0963662515607406$

Bonney, R., Phillips, T. B., Enck, J., Shirk, J., and Trautmann, N. (2014). Citizen Science and Youth Education. National Research Council Committee on Outof-School Time STEM. Washington, DC: National Research Council.

Bovill, C. (2014). An investigation of co-created curricula within higher education in the UK, Ireland and the USA. Innov. Educ. Teach. Int. 51, 15-25. doi: 10.1080/14703297.2013.770264

Bowser, A., Hansen, D., He, Y., Boston, C., Reid, M., Gunnell, L., et al. (2013). "Using gamification to inspire new citizen science volunteers," in Proceedings of the First International Conference on Gameful Design, Research, and Applications, Vol. 1 (Stratford, ON), 18-25. doi: 10.1145/2583008. 2583011

Brossard, D., Lewenstein, B., and Bonney, R. (2005). Scientific knowledge and attitude change: the impact of a citizen science project. Int. J. Sci. Educ. 27, 1099-1121. doi: 10.1080/09500690500069483

Bunce, L., Baird, A., and Jones, S. E. (2017). The student-as-consumer approach in higher education and its effects on academic performance. Stud. Higher Educ. 42, 1958-1978. doi: 10.1080/03075079.2015.1127908

Burls, K., and Recknagel, G. (2013). Approaches to Active Citizens Learning: A Review of Policy and Practice 2010-2013. Lincoln: Take Part Research Cluster.

COST (2016). COST Action CA15212: Citizen Science to Promote Creativity, Scientific Literacy, and Innovation Throughout Europe. Available Online at: https://www.cs-eu.net (accessed July 10, 2019).

Crall, A. W., Jordan, R., Holfelder, K., Newman, G. J., Graham, J., and Waller, D. M. (2013). The impacts of an invasive species citizen science training program on participant attitudes, behavior, and science literacy. Public Underst. Sci. 22, 745-764. doi: $10.1177 / 0963662511434894$
Dawson, E. (2014). "Not designed for us": how science museums and science centers socially exclude low-income, minority ethnic groups. Sci. Educ. 98, 981-1008. doi: 10.1002/sce.21133

Dawson, T., Hambly, J., Kelley, A., Lees, W., and Miller, S. (2020). Coastal heritage, global climate change, public engagement, and citizen science. Proc. Natl. Acad. Sci. U.S.A. 117, 8280-8286. doi: 10.1073/pnas.1912246117

Dearing, R. (1997). Higher Education in the Learning Society: Report of the National Committee of Inquiry Into Higher Education. London: Her Majesty's Stationary Office.

Dickinson, J. L., Shirk, J., Bonter, D., Bonney, R., Crain, R. L., Martin, J., et al. (2012). The current state of citizen science as a tool for ecological research and public engagement. Front. Ecol. Environ. 10, 291-297. doi: 10.1890/110236

Dillon, J., Stevenson, R. B., and Wals, A. E. J. (2016). Moving from citizen to civic science to address wicked conservation problems. Conserv. Biol. 30, 450-455. doi: $10.1111 /$ cobi.12689

Doyle, C., David, R., Li, Y., Luczak-Roesch, M., Anderson, D., and Pierson, C. M. (2019). "Using the web for science in the classroom: online citizen science participation in teaching and learning," in Proceedings of the 11th ACM Conference on Web Science (Massachusetts), 71-80. doi: $10.1145 / 3292522.3326022$

Eberbach, C., and Crowley, K. (2009). From everyday to scientific observation: how children learn to observe the biologist's world. Rev. Educ. Res. 79, 39-68. doi: 10.3102/0034654308325899

Edwards, R. (2014). Citizen science and lifelong learning. Stud. Educ. Adult. 46, 132-144. doi: 10.1080/02660830.2014.11661662

Edwards, R., Kirn, S., Hillman, T., Kloetzer, L., Mathieson, K., McDonnell, D., et al. (2018). "Learning and developing science capital through citizen science," in Citizen Science: Innovation in Open Science, Society and Policy, eds S. Hecker, M. Haklay, A. Bowser, Z. Makuch, J. Vogel, and A. Bonn (London: UCL Press), 381-390. doi: $10.2307 /$ j.ctv550cf2.33

Eichler, S. E., Hopperton, A. P., Alava, J. J., Pereira, A. Jr., Ahmed, R., Kozlakidis, Z., et al. (2020). A citizen science facemask experiment and educational modules to improve coronavirus safety in communities and schools. Front. Med. 7:486. doi: $10.3389 /$ fmed.2020.00486

Eitzel, M. V., Cappadonna, J. L., Santos-Lang, C., Duerr, R. E., Virapongse, A., West, S. E., et al. (2017). Citizen science terminology matters: exploring key terms. Citiz. Sci. Theory Pract. 2, 1-20. doi: 10.5334/cstp.96

Eshach, H. (2007). Bridging in-school and out-of-school learning: Formal, nonformal, and informal education. Journal of science education and technology, 16, 171-190. doi: 10.1007/s10956-006-9027-1

European Citizen Science Association (2015). Ten Principles of Citizen Science. Available online at: https://ecsa.citizen-science.net/sites/default/files/ecsa_ten_ principles_of_citizen_science.pdf (accessed July 6, 2020).

European Citizen Science Association (2020). ECSA's Characteristics of Citizen Science: Explanation Notes. Available online at: https://ecsa.citizen-science. net/sites/default/files/ecsa_characteristics_of_citizen_science_explanation_ notes_-_v1_final.pdf (accessed July 6, 2020).

European Commission (2017). Horizon 2020 Work Programme 2018-2020. Science with and for Society. Available online at: https://ec.europa.eu/programmes/ horizon2020/en/h2020-section/science- and-society (accessed July 6, 2020).

Fazio, X., and Karrow, D. D. (2015). "The commonplaces of schooling and citizen science," in Ecojustice, Citizen Science and Youth Activism, ed M. P. Mueller (Cham: Springer), 179-191. doi: 10.1007/978-3-319-11608-2_11

Fiske, A., Prainsack, B., and Buyx, A. (2019). Meeting the needs of underserved populations: setting the agenda for more inclusive citizen science of medicine. J. Med. Ethics 45, 617-622. doi: 10.1136/medethics-2018-105253

Fraisl, D., Campbell, J., See, L., Wehn, U., Wardlaw, J., Gold, M., et al. (2020). Mapping citizen science contributions to the UN sustainable development goals. Sustain. Sci. 15, 1-17. doi: 10.1007/s11625-020-00833-7

Freeman, S., Eddy, S. L., McDonough, M., Smith, M. K., Okoroafor, N., Jordt, H., et al. (2014). Active learning increases student performance in science, engineering, and mathematics. Proc. Natl. Acad. Sci. U.S.A. 111, 8410-8415. doi: $10.1073 /$ pnas.1319030111

Fritz, S., See, L., Carlson, T., Haklay, M. M., Oliver, J. L., Fraisl, D., et al. (2019). Citizen science and the United Nations sustainable development goals. Nat. Sustain. 2, 922-930. doi: 10.1038/s41893-019-0390-3

Gleason, B., and Von Gillern, S. (2018). Digital citizenship with social media: participatory practices of teaching and learning in secondary education. J. Educ. 
Technol. Soc. 21, 200-212. Available online at: https://www.jstor.org/stable/ 26273880 ?seq=1\#metadata_info_tab_contents

Golumbic, Y. N., Orr, D., Baram-Tsabari, A., and Fishbain, B. (2017). Between vision and reality: a case study of scientists' views on citizen science. Citiz. Sci. Theory Pract. 2, 1-13. doi: 10.5334/cstp.53

Gray, S. A., Nicosia, K., and Jordan, R. C. (2012). Lessons learned from citizen science in the classroom. a response to "the future of citizen science." Democr. Educ. 20:14. Available online at: https://democracyeducationjournal.org/home/ vol20/iss2/14/

Groulx, M., Brisbois, M. C., Lemieux, C. J., Winegardner, A., and Fishback, L. (2017). A role for nature-based citizen science in promoting individual and collective climate change action? A systematic review of learning outcomes. Sci. Commun. 39, 45-76. doi: 10.1177/1075547016688324

Haklay, M. (2013). "Citizen science and volunteered geographic information - overview and typology of participation," in Crowdsourcing Geographic Knowledge: Volunteered Geographic Information (VGI) in Theory and Practice, eds D. Z. Sui, S. Elwood, and M. F. Goodchild (Berlin: Springer), 105-122. doi: 10.1007/978-94-007-4587-2 7

Haywood, B. K., and Besley, J. C. (2013). Education, outreach, and inclusive engagement: towards integrated indicators of successful program outcomes in participatory science. Public Underst. Sci. 23, 92-106. doi: 10.1177/0963662513494560

Haywood, B. K., Parrish, J. K., and Dolliver, J. (2016). Place-based and datarich citizen science as a precursor for conservation action. Conserv. Biol. 30, 476-486. doi: 10.1111/cobi.12702

Healey, M., Flint, A., and Harrington, K. (2016). Students as partners: reflections on a conceptual model. Teach. Learn. Inq. 4, 1-13. doi: 10.20343 /teachlearninqu.4.2.3

Henderson, J., Ward, P. R., Tonkin, E., Meyer, S. B., Pillen, H., McCullum, D., et al. (2020). Developing and maintaining public trust during and post-COVID-19: can we apply a model developed for responding to food scares? Front. Public Health 8:369. doi: 10.3389/fpubh.2020.00369

Hutter, S., and Kriesi, H. (2019). Politicizing Europe in times of crisis. J. Eur. Public Policy 26, 996-1017. doi: 10.1080/13501763.2019.1619801

Jeanpierre, B., Oberhauser, K., and Freeman, C. (2005). Characteristics of professional development that affect change in secondary science teachers' classroom practices. J. Res. Sci. Teach. 42, 668-690. doi: 10.1002/tea.20069

Jenkins, E. W. (2006). The student voice and school science education. Stud. Sci. Educ. 42, 49-88. doi: 10.1080/03057260608560220

Jenkins, L. L. (2011). Using citizen science beyond teaching science content: a strategy for making science relevant to students' lives. Cult. Stud. Sci. Educ. 6, 501-508. doi: 10.1007/s11422-010-9304-4

Jenkins, L. L., Walker, R. M., Tenenbaum, Z., Sadler, K. C., and Wissehr, C. (2015). "Why the secret of the great smoky mountains institute at tremont should influence science education-connecting people and nature," in EcoJustice, Citizen Science and Youth Activism, ed M. P. Mueller (Cham: Springer), 265-279. doi: 10.1007/978-3-319-11608-2_16

Jordan, R., Crall, A., Gray, S., Phillips, T., and Mellor, D. (2015). Citizen science as a distinct field of inquiry. BioScience 65, 208-211. doi: 10.1093/biosci/biu217

Jordan, R. C., Gray, S. A., Howe, D. V., Brooks, W. R., and Ehrenfeld, J. G. (2011). Knowledge gain and behavioral change in citizen-science programs. Conserv. Biol. 25, 1148-1154. doi: 10.1111/j.1523-1739.2011.01745.x

Kalekin-Fishman, D., Tsitselikis, K., and Pitkänen, P. (2007). "Theorizing multiple citizenship," in Multiple Citizenship as a Challenge to European Nation-States, ed P. Kalekin-Fishman (Leiden: Brill Sense), 1-38. doi: 10.1163/97890879 01653

Kelemen-Finan, J., and Dedova, I. (2014). Vermittlung von Artenkenntnis im Schulunterricht. Ergebnisse einer Befragung von Lehrpersonal in Österreich und bildungspolitische Relevanz. Naturschutz und Landschaftsplanung 46, 219-225.

Kelemen-Finan, J., Scheuch, M., and Winter, S. (2018). Contributions from citizen science to science education: an examination of a biodiversity citizen science project with schools in Central Europe. Int. J. Sci. Educ. 40, 2078-2098. doi: 10.1080/09500693.2018.1520405

Kermish-Allen, R., Peterman, K., and Bevc, C. (2019). The utility of citizen science projects in K-5 schools: measures of community engagement and student impacts. Cult. Stud. Sci. Educ. 14, 627-641. doi: 10.1007/s11422-017-9830-4

Kerzner, H. R. (2013). Project Management: A Systems Approach to Planning, Scheduling, and Controlling, 11th Edn. Hoboken, NJ: John Wiley and Sons.
Khazragui, H., and Hudson, J. (2015). Measuring the benefits of university research: impact and the REF in the UK. Res. Eval. 24, 51-62. doi: $10.1093 / \mathrm{reseval} / \mathrm{rvu} 028$

Kountoupes, D. L., and Oberhauser, K. S. (2008). Citizen science and youth audiences: educational outcomes of the Monarch Larva Monitoring Project. J. Commun. Engag. Sch. 1:1. Available online at: https://digitalcommons. northgeorgia.edu/jces/vol1/iss1/5/

Kreiman, G., and Maunsell, J. H. R. (2011). Nine criteria for a measure of scientific output. Front. Comput. Neurosci. 5, 1-6. doi: 10.3389/fncom.2011.00048

Kythreotis, A. P., Mantyka-Pringle, C., Mercer, T. G., Whitmarsh, L. E., Corner, A., Paavola, J., et al. (2019). Citizen social science for more integrative and effective climate action: a science-policy perspective. Front. Environ. Sci. 7:10. doi: 10.3389/fenvs.2019.00010

Leibowitz, B. (2017). Power, knowledge and learning: dehegomonising colonial knowledge. Altern. J. 24, 99-119. doi: 10.29086/2519-5476/2017/v24n2a6

Letiecq, B. L., and Anderson, E. A. (2017). From education to advocacy and activism: a lternative approaches for translating family science to policy. Fam. Relat. 66, 729-740. doi: 10.1111/fare.12274

Lewandowski, E., Caldwell, W., Elmquist, D., and Oberhauser, K. (2017). Public perceptions of citizen science. Citiz. Sci. Theory Pract. 2, 1-9. doi: $10.5334 /$ cstp.77

Lewenstein, B. V. (2015). Identifying what matters: science education, science communication, and democracy. J. Res. Sci. Teach. 52, 253-262. doi: $10.1002 /$ tea.21201

Lorke, J., Golumbic, Y. N., Ramjan, C., and Atias, O. (2019). Training needs and recommendations for citizen science participants, facilitators and designers. COST Action 15212 reportAQ publisher.

Lucky, A., Savage, A. M., Nichols, L. M., Castracani, C., Shell, L., Grasso, D. A., et al. (2014). Ecologists, educators, and writers collaborate with the public to assess backyard diversity in The School of Ants Project. Ecosphere 5, 1-23. doi: 10.1890/ES13-00364.1

Mannion, G., Fenwick, A., and Lynch, J. (2013). Place-responsive pedagogy: learning from teachers' experiences of excursions in nature. Environ. Educ. Res. 19, 792-809. doi: 10.1080/13504622.2012.749980

McCallie, E., Bell, L., Lohwater, T., Falk, J. H., Lehr, J. L., Lewenstein, B. V., et al. (2009). Many experts, many audiences: public engagement with science and informal science education, A CAISE Inquiry Group Report (March: CAISE), 1-83.

McCulloch, A. (2009). The student as co-producer: learning from public administration about the student-university relationship. Stud. Higher Educ. 34, 171-183. doi: 10.1080/03075070802562857

Mercer, N., and Littleton, K. (2007). Dialogue and the Development of Children's Thinking: A Sociocultural Approach. Oxfordshire: Routledge. doi: 10.4324/9780203946657

Miller, J. D. (1983). Scientific literacy: a conceptual and empirical review. Daedalus 112, 29-48.

Morschheuser, B., Hamari, J., and Maedche, A. (2019). Cooperation or competition-when do people contribute more? A field experiment on gamification of crowdsourcing. Int.J. Hum-Comput. Stud. 127, 7-24. doi: 10.1016/j.ijhcs.2018.10.001

Mueller, M., and Tippins, D. J. (2015). Ecojustice, Citizen Science and Youth Activism. Dordrecht: Springer.

Mueller, M. P., and Tippins, D. J. (2012). "Citizen science, ecojustice, and science education: rethinking an education from nowhere," in Second International Handbook of Science Education, eds B. J. Fraser, K. Tobin, and C. McRobbie (New York, NY: Springer), 856-882. doi: 10.1007/978-1-4020-9041-7_58

National Academies of Sciences, Engineering, and Medicine (2018). Learning Through Citizen Science: Enhancing Opportunities by Design. Washington, DC: The National Academies Press.

National Research Council (2009). Learning Science in Informal Environments: People, Places, and Pursuits. Washington, DC: The National Academies Press.

Newman, G., Wiggins, A., Crall, A., Graham, E., Newman, S., and Crowston, K. (2012). The future of citizen science: emerging technologies and shifting paradigms. Front. Ecol. Environ. 10, 298-304. doi: 10.1890/110294

Olteanu-Raimond, A. M., Jolivet, L., Van Damme, M. D., Royer, T., Fraval, L., See, L., et al. (2018). An experimental framework for integrating citizen and community science into land cover, land use, and land change detection processes in a National Mapping Agency. Land 7:103. doi: 10.3390/land7030103 
Owen, R., Macnaghten, P., and Stilgoe, J. (2012). Responsible research and innovation: from science in society to science for society, with society. Sci. Public Policy 39, 751-760. doi: 10.1093/scipol/scs093

Palfreyman, D., and Warner, D. (1998). Higher Education and the Law: A Guide for Managers. Buckingham: Open University Press.

Phillips, T., Porticella, N., Constas, M., and Bonney, R. (2018). A framework for articulating and measuring individual learning outcomes from participation in citizen science. Citiz. Sci. Theory Pract. 3:3. doi: 10.5334/cstp.126

Phillips, T. B., Ferguson, M., Minarchek, M., Porticella, N., and Bonney, R. (2014). User's Guide for Evaluating Learning Outcomes in Citizen Science. Ithaca, NY: Cornell Lab of Ornithology.

Piper, A. (2020). Digital crowdsourcing and public understandings of the past: citizen historians meet criminal characters. Hist. Aust. 17, 525-541. doi: 10.1080/14490854.2020.1796500

Provenzi, L., and Barello, S. (2020). The science of the future: Establishing a citizen-scientist collaborative agenda after Covid-19. Front. Public Health 8:282. doi: 10.3389/fpubh.2020.00282

Pykett, J., Chrisinger, B., Kyriakou, K., Osborne, T., Resch, B., Stathi, A., et al. (2020). Developing a citizen social science approach to understand urban stress and promote wellbeing in urban communities. Palgrave Commun. 6, 1-11. doi: 10.1057/s41599-020-0460-1

Reis, P. (2020). "Environmental citizenship and youth activism," in Conceptualizing Environmental Citizenship for 21st Century Education (Cham: Springer), 139-148. doi: 10.1007/978-3-030-20249-1_9

Riesch, H., and Potter, C. (2014). Citizen science as seen by scientists: methodological, epistemological and ethical dimensions. Public Underst. Sci. 23, 107-120. doi: 10.1177/0963662513497324

Roche, J., and Davis, N. (2017a). Citizen science: an emerging professional field united in truth-seeking. J. Sci. Commun. 16, 1-6. doi: 10.22323/2.16040601

Roche, J., and Davis, N. (2017b). Should the science communication community play a role in political activism? J. Sci. Commun. 16, 1-4. doi: $10.22323 / 2.16010101$

Saunders, M. E., Roger, E., Geary, W. L., Meredith, F., Welbourne, D. J., Bako, A., et al. (2018). Citizen science in schools: engaging students in research on urban habitat for pollinators. Aust. Ecol. 43, 635-642. doi: 10.1111/aec.12608

Scheuch, M., Panhuber, T., Winter, S., Kelemen-Finan, J., Bardy-Durchhalter, M., and Kapelari, S. (2018). Butterflies and wild bees: biology teachers' PCK development through citizen science. J. Biol. Educ. 52, 79-88. doi: 10.1080/00219266.2017.1405530

Scheufele, D. A., and Krause, N. M. (2019). Science audiences, misinformation, and fake news. Proc. Natl Acad. Sci. 116, 7662-7669. doi: 10.1073/pnas.1805871115

Schuttler, S. G., Sears, R. S., Orendain, I., Khot, R., Rubenstein, D., Rubenstein, N., et al. (2019). Citizen science in schools: students collect valuable mammal data for science, conservation, and community engagement. Bioscience 69, 69-79. doi: 10.1093/biosci/biy141

Scott, D. M. (2013). The New Rules of Marketing and PR: How to Use Social Media, Online Video, Mobile Applications, Blogs, News Releases, and Viral Marketing to Reach Buyers Directly, 4th Edn. Hoboken, NJ: John Wiley.

Shirk, J., Ballard, H., Wilderman, C., Phillips, T., Wiggins, A., Jordan, R., et al. (2012). Public participation in scientific research: a framework for deliberate design. Ecol. Soc. 17:29. doi: 10.5751/ES-04705-170229

Smith, K. M., Else, F., and Crookes, P. A. (2014). Engagement and academic promotion: a review of the literature. Higher Educ. Res. Dev. 33, 836-847. doi: 10.1080/07294360.2013.863849

Socientize Consortium (2013). "Green Paper on citizen science: citizen science for Europe: towards a better society of empowered citizens and enhanced research," in European Commission, (Brussels) 1-54.

Socientize Consortium (2014). "White Paper on citizen science." in European Commission, 1-35.

Soleri, D., Long, J. W., Ramirez-Andreotta, M. D., Eitemiller, R., and Pandya, R. (2016). Finding pathways to more equitable and meaningful public-scientist partnerships. Citiz. Sci. Theory Pract. 1:9. doi: 10.5334/cstp.46
Stetsenko, A. (2008). From relational ontology to transformative activist stance on development and learning: expanding Vygotsky's (CHAT) project. Cult. Stud. Sci. Educ. 3, 471-491. doi: 10.1007/s11422-0089111-3

Stewart, O. G., and Jordan, M. E. (2017). "Some explanation here": a case study of learning opportunities and tensions in an informal science learning environment. Instr. Sci. 45, 137-156. doi: 10.1007/s11251-016-9396-7

Storksdieck, M., Shirk, J., Cappadonna, J., Domroese, M., Göbel, C., Haklay, M., et al. (2016). Associations for citizen science: regional knowledge, global collaboration. Citiz. Sci. Theory Pract. 1, 1-10. doi: 10.5334/cstp. 55

Tauginiene, L., Butkevičiene, E., Vohland, K., Heinisch, B., Daskolia, M., Suškevičs, M., et al. (2020). Citizen science in the social sciences and humanities: the power of interdisciplinarity. Palgrave Commun. 6, 1-11. doi: 10.1057/s41599-020-0471-y

Tippins, D. J., and Jensen, L. J. (2012). Citizen science in digital worlds: the seduction of a temporary escape or a lifelong pursuit? Cult. Stud. Sci. Educ. 7, 851-856. doi: 10.1007/s11422-012-9463-6

Trench, B. (2008). “Towards an analytical framework of science communication models," in Communicating Science in Social Contexts. New Models New Practces, eds D. Cheng, M. Claessens, T. Gascoigne, J. Metcalfe, B. Schiele, and S. Shi (Dordrecht: Springer), 119-135

Tulloch, A. I., Possingham, H. P., Joseph, L. N., Szabo, J., and Martin, T. G. (2013). Realising the full potential of citizen science monitoring programs. Biol. Conserv. 165, 128-138. doi: 10.1016/j.biocon.2013.05.025

Ugolini, F., Massetti, L., Calaza-Martínez, P., Cariñanos, P., Dobbs, C., Ostoic, S. K., et al. (2020). Effects of the Covid-19 pandemic on the use and perceptions of urban green space: an international exploratory study. Urban For. Urban Gree. 56, 1-9. doi: 10.1016/j.ufug.2020.126888

UNESCO (2015). Education 2030: Incheon Declaration: Towards Inclusive and Equitable Quality Education and Lifelong Learning for All. Paris: UNESCO Institute for Longlife Learning.

Van Vliet, A. J., Bron, W. A., and Mulder, S. (2014). The how and why of societal publications for citizen science projects and scientists. Int. J. Biometeorol. 58, 565-577. doi: 10.1007/s00484-014-0821-9

Veeckman, C., Talboom, S., Gijsel, L., Devoghel, H., and Duerinckx, A. (2019). Communication in Citizen Science. A Practical Guide to Communication and Engagement in Citizen Science. Leuven: SCIVIL.

Watermeyer, R. (2016). Impact in the REF: issues and obstacles. Stud. Higher Educ. 41, 199-214. doi: 10.1080/03075079.2014.915303

Weinstein, M. (2012). Schools/citizen science. A response to "the future of citizen science". Democr. Educ. 20:6. Available online at: https:// democracyeducationjournal.org/home/vol20/iss1/6/

Werquin, P. (2007). Terms, Concepts and Models for Analysing the Value of Recognition of Non-formal and Informal Learning Programmes. Working Paper prepared for the OECD activity on the Recognition of non-formal and informal learning. Vienna: OECD.

Zoellick, B., Nelson, S. J., and Schauffler, M. (2012). Participatory science and education: bringing both views into focus. Front. Ecol. Environ. 10, 310-313. doi: $10.1890 / 110277$

Conflict of Interest: The authors declare that the research was conducted in the absence of any commercial or financial relationships that could be construed as a potential conflict of interest.

Copyright (c) 2020 Roche, Bell, Galvão, Golumbic, Kloetzer, Knoben, Laakso, Lorke, Mannion, Massetti, Mauchline, Pata, Ruck, Taraba and Winter. This is an openaccess article distributed under the terms of the Creative Commons Attribution License (CC BY). The use, distribution or reproduction in other forums is permitted, provided the original author(s) and the copyright owner(s) are credited and that the original publication in this journal is cited, in accordance with accepted academic practice. No use, distribution or reproduction is permitted which does not comply with these terms. 